\title{
Phytosociology-A Useful Tool for the Assessment of Past and Future Human Impacts on Plants and Forest Ecosystems
}

\author{
Monika Konatowska, Paweł Rutkowski \\ Department of Forest Sites and Ecology, Faculty of Forestry, Poznań University of Life Sciences, Poznań, Poland \\ Email: monika.konatowska@up.poznan.pl
}

How to cite this paper: Konatowska, M. and Rutkowski, P. (2019) Phytosociology-A Useful Tool for the Assessment of Past and Future Human Impacts on Plants and Forest Ecosystems. Journal of Biosciences and Medicines, 7, 154-163.

https://doi.org/10.4236/jbm.2019.711014

Received: October 27, 2019

Accepted: November 24, 2019

Published: November 27, 2019

\begin{abstract}
The aim of this research was to answer the question of whether the floristicphytosociological characteristics of the forest communities described in the mid-twentieth century in the Zielonka Experimental Forest (Poland) have changed, and if so, what were the reasons for these changes and what were their environmental and economic consequences. The basis of the research was a comparison of plant community descriptions drawn up in 1957-1961 to descriptions of the states of those communities in 2010-2017. The study showed a significant decrease in the number of plant species. The reasons for the disappearance of some plant communities are seen in the natural or artificial changes of pine in sandy habitats, which evolved towards richer communities. The disappearance of xero-thermophile oak woods had two main causes: a natural cause, which was a consequence of regeneration towards oak-hornbeam woods after the anthropogenic phenomena responsible for their management, and anthropogenic disturbance related to the planting of Fagus sylvatica trees or Prunus serotina. The second case is described more broadly and considers both the positive and negative roles of changing the floristic compositions of forest ecosystems.
\end{abstract}

\section{Keywords}

Phytosociology, Forest Management, Prunus serotina

\section{Introduction}

Under natural conditions, habitat factors (e.g., soil, climate, location) determine the growth and development of plants. These natural factors are superimposed on human activity, which is increasingly changing the plant cover. The pace of 
these changes can be assessed in different ways. One method that documents the current floristic composition is a phytosociological plot (relevé), a basic element of description in the field called phytosociology. Phytosociology is a botanical science as well as being part of the discipline of ecology. It describes vegetation and individual communities [1]. The essence of phytosociological relevés is to compile a list of plants in a given area, including the degree of coverage for each species expressed either as a percentage [2] or by using the scale provided by Braun-Blanquet [3]. The value of phytosociological data grows over time provided that the locations of the plants are well documented to allow repeated studies in the same place. The juxtaposition of relevés taken at different intervals allows the capture of vegetation changes that are taking place and thus aids the interpreting these changes. This is also the purpose of this article, which is based on selected relevés describing the forest ecosystem that were conducted by Nowaczyk [4]. The directions and effects of the changes were investigated by considering the natural and economic consequences.

There are many methods for studying plant cover transformation. They can be carried out at the species level and at the level of phytocoenoses [5]. However, it seems that a common feature should be observations carried out in well-defined research plots [6]. These types of observations have been carried out in different parts of the world and in different types of plant communities. In Canada, the results of a 40-year study of the alpine floor tundra were published by Danby et al. [7], pointing to an increase in the number of species in the studied communities and linking this fact to global warming. Holzinger et al. [8], Kullman [9], Vittoz et al. [10] and Odland et al. [11], obtained similar results for alpine and subarctic communities. Becker et al. [12] presented the results from 40 years of observations of vegetation changes in former coppice forests in the central part of Germany and indicated that the reasons for the changes were associated with the manner of development as well as with eutrophication with nitrogen compounds.

Despite the clear advantages of permanent experimental plots, their main disadvantages are their limited temporal and spatial extents [13]. Most field observations and experiments are short-term and yield quite limited knowledge regarding the dynamics of ecosystems operating under the influence of long-term factors [13]. The period of this type of research usually does not exceed several decades, with a few exceptions, e.g. [14]. Therefore, as an alternative to long-term observations of permanent research plots, Hedl et al. [13] reported retrospective studies. The concept underlying this type of research is not new. It was described in 1929 by Conard and Galligar [15]. In turn, the disadvantages of reproducing vegetation descriptions in a given area are mainly associated with possible shifts in the compared areas, as well as the subjectivity of the observer [16]. These two sources of undesirable variation between the first study and repeated studies cannot be completely removed, although their impacts can be estimated [17] [18]. 
However, these restrictions do not affect the level of interest in the subject, as exemplified by the congress held in Brno (Czech Republic) in 2015, at which four papers on wetlands were presented [19] [20] [21] [22], four forest ecosystems [12] [23] [24] [25], three grassland ecosystems [26] [27] [28]; one Arctic ecosystem [16] and one coastal vegetation ecosystem were addressed [29].

\section{Material and Methods}

The basis of this study was a comparison of plant community descriptions made by Nowaczyk [4] in 1957-1961 with the current states of those plant communities.

The reconstruction of research plots consisted of converting a copy of the author's manuscript map into digital form and creating a numeric map layer in the ArcGIS 10 software. This procedure allowed the determination of geographical coordinates for the research plots described by Nowaczyk to mark field locations, which provided the basis for comparative studies. The GPSmap $62^{\text {st }}$ device was used to locate the plots in the field using geographical coordinates, and the measurement accuracies for the conditions of the research area varied up to several meters.

The size of the research areas established by Nowaczyk ranged from $200-400$ $\mathrm{m}^{2}$ and was occasionally as large as $500 \mathrm{~m}^{2}$. For the comparative studies, the size of the research areas was standardized to $400 \mathrm{~m}^{2}$, and this approach combined with the abovementioned accuracy in determining the locations in the field resulted in no additional significant impacts on the test results. However, considering the above information, the comparative studies focused more on qualitative changes in the composition of the undergrowth than on quantitative changes within the described plant species.

The descriptions of the phytosociological relevés, similar to those prepared by Nowaczyk, were prepared in accordance with the Braun-Blanquet method, which is commonly used in this respect.

All of the initial phytosociological plots described by Nowaczyk, after comparing them with the present state, were grouped into pairs, which enabled capture of the differences between the individual research areas. These differences were determined by compiling, for each relevé, a list of species that had disappeared in a given place, a list of species that had entered over the past several decades, and a list of species that had been recorded by both Nowaczyk and that are currently present.

The nomenclature of plant associations follows Matuszkiewicz [30].

\section{Results}

To highlight past and future human impacts on plants and forest ecosystems, two pairs of phytosociological relevés with similar habitat condition characteristics were selected in the experimental forests belonging to the Poznań University of Life Sciences (Poland). The soils of the studied areas were created from loose outwash sands with acidic reactions and are in a climate with current relatively 
low average annual rainfall, are in a zone that is typical for a moderate climate, and have an average annual temperature oscillating at approximately $8^{\circ} \mathrm{C}$ (Figure 1). In such conditions, in the lowland part of Poland, the forest-forming species are pine (Pinus sylvestris), oak (Quercus petraea \& Q. robur), hornbeam (Carpinus betulus) and beech (Fagus sylvatica). For several dozen years, Prunus serotina, introduced to Poland in 1813 [31] [32], has been growing increasingly intensively, and in the area of the Zielonka Experimental Forest, where the research was conducted, it appeared in 1949 [33]. Depending on the species compositions of the stands, which is affected not only by habitat conditions but also by forest management, the following plant communities may exist: Leucobryo-Pinetum, Querco roboris-Pinetum, Calamagrostio arundinaceae-Quercetum petraeae, Potentillo albae-Quercetum, Galio sylvatici-Carpinetum, Luzulo pilosae-Fagetum, and Fago-Quercetum, and where the bird cherry dominates, substitute communities with bird cherry participation form (Figure 1). Some of the communities play a special role in the European nature protection system (Natura 2000), requiring proper care of their conditions. These communities are marked in bold and have a darker background in Figure 1.

The communities used as examples are marked in this paper by the letters $\mathrm{A}$ and B. In 1952, community A consisted of pine with ages of 75 - 80 years. Occasionally, an oak tree with the same age range was present. For $20 \%$ of the area, oaks with ages of 8 - 12 years were planted. In the phytosociological relevé performed in 1960 by Nowaczyk [4], this location was described as the Pino-Quercetum plant association (according to the current nomenclature of Querco roboris-Pinetum). The author of the description noted 32 species of vascular plants and 3 species of mosses.

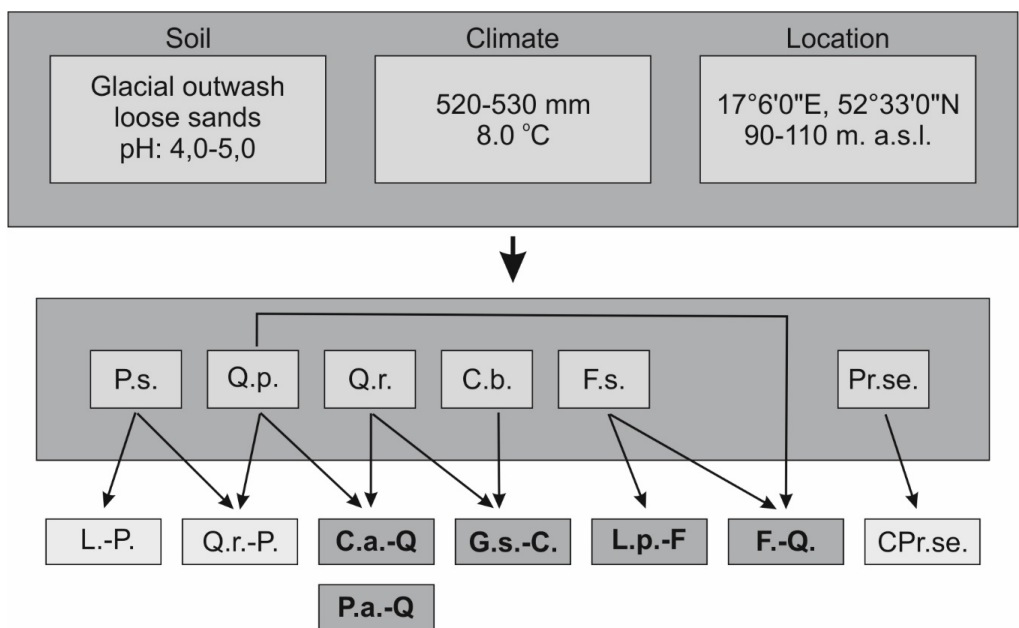

Abbreviations: P.s.-Pinus sylvestris; Q.p.-Quercus petraea; Q.r.-Q. robur, C.b.-Carpinus betulus; F.s._Fagus sylvatica; Pr.se.-Prunus serotina; L.-P._Leucobryo-Pinetum; Q.r.-P.-Querco roboris-Pinetum; C.a.-Q-Calamagrostio arundinaceae-Quercetum; P.a.-Q.-Potentillo albae-Quercetum; G.s.-C-Galio sylvatici-Carpinetum; L.p.-F.-Luzulo pilosae-Fagetum; F.-Q.-Fago-Quercetum; CPr.se.-plant community formed by Prunus serotina.

Figure 1. Impacts of habitat factors on the species compositions of stands and plant communities. 
The phytosociological relevé, repeated in 2018 by Konatowska [34], found only 8 species, including 7 vascular plants and one moss, with only 4 species showing a permanent presence (Betula pendula, Picea abies, Pinus sylvestris and Quercus petraea). Between 1960-2018, 31 species disappeared, and 4 new ones appeared in this area, including Prunus serotina (Figure 2).

The appearance of Prunus serotina played a key role in the history of changes to plant cover in relevé area A. This species was not noted in 1960 in this area, while in 2018, it formed a layer of shrubs with a coverage of 75\% - 100\% (grade 5 on the Braun-Blanquet scale) and had displaced most species from the forest floor by shading or through allelopathic interaction (or both factors combined).

In 1952, the B plant community was formed by pine with ages of $101-105$ years. The pine was occasionally accompanied by oak and birch. In some places, a hornbeam was present. Beech (Fagus sylvatica) had also been planted in the past, and its age was 18 years in 1952.

The phytosociological studies repeated in 2017 [34] showed the presence of only 15 species (Figure 3 ).

The growth of Fagus sylvatica, planted in approximately 1935 and forming a dense second layer of stand in 2017, played a key role in the history of changes in vegetation cover by shading the forest floor. This led to the elimination of 46 species that were recorded in 1957. However, the beech also played other roles. In part of the forest, $50 \mathrm{~m}$ away, where a beech stand had been cut down, Prunus serotina entered and completely displaced all other species. The floristic comparison for the locations with bird cherry was as follows: $1957-n=55 ; 2017-n$ $=1$. Although the presence of bird cherry under beech stands was also noted in 2017, its proportions were sporadic and were only in the form of seedlings, with no further growth to the next stage of the stand.

In Figure 4, for the final stage of changes noted in research plot A (2018), 8

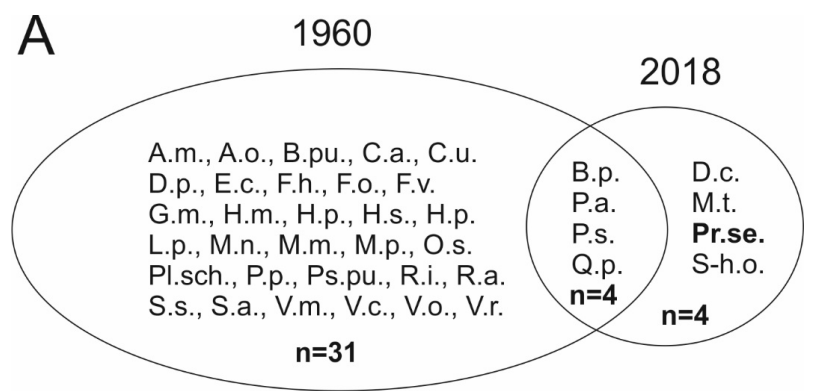

Disappeared: Achillea millefolium, Anthoxanthum odoratum, Betula pubescens, Calamagrostis arundinacea, Chimaphila umbellata, Dicranum polysetum, Euphorbia cyparissias, Festuca heterophylla, Festuca ovina, Fragaria vesca, Galium mollugo, Hieracium murorum, Hieracium pilosella, Hylocomium splendens, Hypericum perforatum, Luzula pilosa, Melampyrum pratense, Melica nutans, Mycelis muralis, Orthilia secunda, Pleurozium schreberi, Poa pratensis, Pseudoscleropodium purum, Rubus idaeus, Rumex acetosella, Senecio sylvaticus, Sorbus aucuparia, Vaccinium myrtillus, Veronica chamaedrys, Veronica officinalis, Viola reichenbachiana.

Appeared: Dryopteris carthusiana, Moehringia trinervia, Prunus serotina, Sciuro-hypnum oedipodium.

Permanent species: Betula pendula, Picea abies, Pinus sylvestris and Quercus petraea.

Figure 2. Differences in species compositions in relevé area A between 1960 and 2018. 


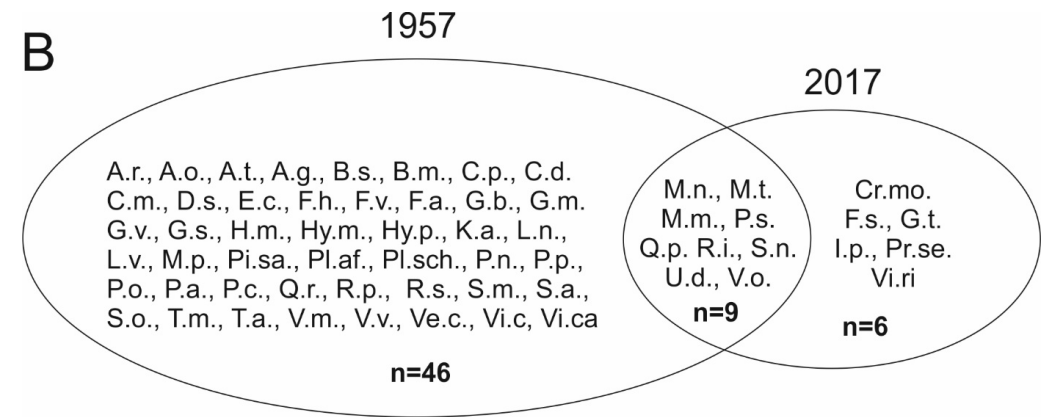

Disappeared: Ajuga reptans, Anthoxanthum odoratum, Asperula tinctoria, Astragalus glycyphyllos, Brachypodium sylvaticum, Briza media, Campanula persicifolia, Carex digitata, Convallaria majalis, Dicranum scoparium, Euphorbia cyparissias, Festuca heterophylla, Fragaria vesca, Frangula alnus, Galium boreale, Galium mollugo, Galium verum, Geranium sanguineum, Hieracium murorum, Hypericum montanum, Hypericum perforatum, Knautia arvensis, Lathyrus niger, Lathyrus vernus, Melampyrum pretense, Pimpinella saxifraga, Plagiomnium affine, Pleurozium schreberi, Poa nemoralis, Poa pratensis, Polygonatum odoratum, Potentilla alba, Pyrus communis, Quercus robur, Ranunculus polyanthemos, Rubus saxatilis, Sedum maximum, Sorbus aucuparia, Stachys officinalis, Thalictrum minus, Trifolium alpestre, Vaccinium myrtillus, Vaccinium vitis-idaea, Veronica chamaedrys, Vicia cassubica, Viola canina.

Appeared: Crataegus monogyna, Fagus sylvatica, Galeopsis tetrahit, Impatiens parviflora, Prunus serotina, Viola riviniana.

Permanent species: Melica nutans, Moehringia trinervia, Mycelis muralis, Pinus sylvestris, Rubus idaeus, Quercus petraea, Silene nutans, Urtica dioica, Veronica officinalis.

Figure 3. Differences in species compositions in relevé area B between 1957 and 2017.

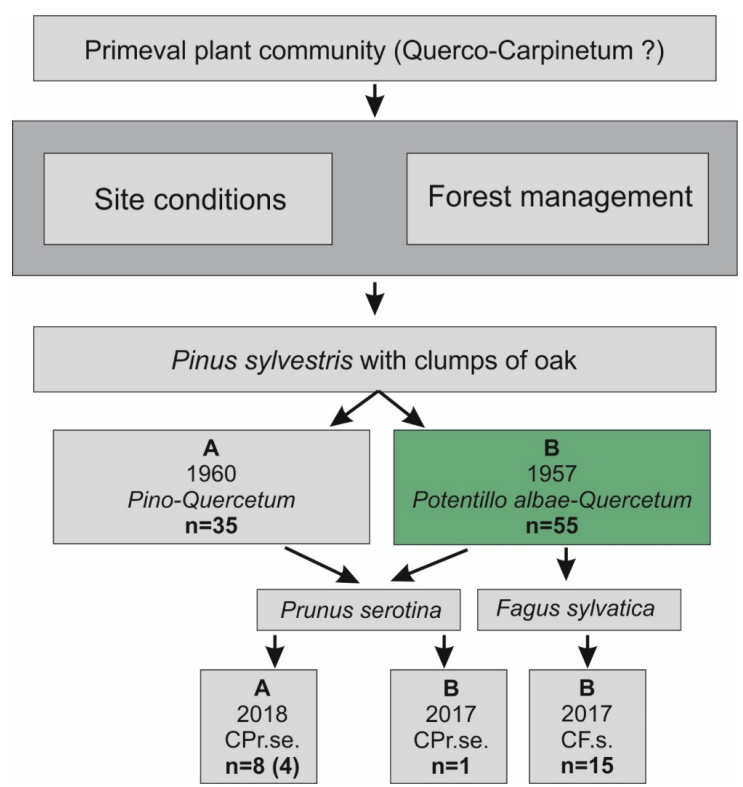

Figure 4. Stages of transformation of the plant cover between 1957-1960 and 2017-2018 and the effects of these changes.

plant species are recorded and an additional 4 species are noted in brackets. The number in brackets is noted because 4 species occurred in the upper layers of the stand (e.g., Betula pendula, Picea abies, Pinus sylvestris and Quercus petraea), without any influence from Prunus serotina on these species. However, the absence of a young generation of these four tree species suggests that they will subside in the coming years. 


\section{Discussion}

The changes shown in Figure 5 are only some of the consequences resulting from the changes in plant cover over the documented 60 years. They do not reflect, among other factors, the impact of species disappearances on the fauna. It is enough to mention that among the species that have disappeared, there are a number of plants that are important for forest bees and bumblebees, which are showing a global decreasing trend. Additionally, the expansion of Prunus serotina, which is not consumed by herbivores in Poland, can lead to concentrations of damage in other parts of forests, where species attractive to deer and other animals remain.

From a natural point of view, a significant negative effect of the changes in vegetation is the loss of natural plant communities, some of which have the status of natural habitats and are protected in the EU under the Natura 2000 network. Restoration of these habitats, if such attempts were made, would need to be associated with the restoration of species providing strong shading, of which, for the described habitat conditions, Carpinus betulus would be the most appropriate. The problem with this species, however, is that it has always been of low value in Polish forestry. Hence, its long-term elimination is related to forest management systems and the replacement of the hornbeam by pines and oaks, which was influenced by the higher economic value of the pines and oaks. This type of forest management created an ecological niche after the elimination of hornbeam in its habitats, and this niche was filled by Prunus serotina. At present, the costs of fighting the bird cherry should be added to economic calculations. Analysis of the complex environmental and economic consequences could be the subject of a separate study. This publication focuses only on demonstrating what types of information phytosociological work provides when comparing data obtained at different times. The authors are also aware of the labor intensity of this type of study, which in some regions of the world, may be difficult to carry out in a traditional, terrestrial manner with descriptions made directly by a researcher. Hence, there is a need to improve the techniques of

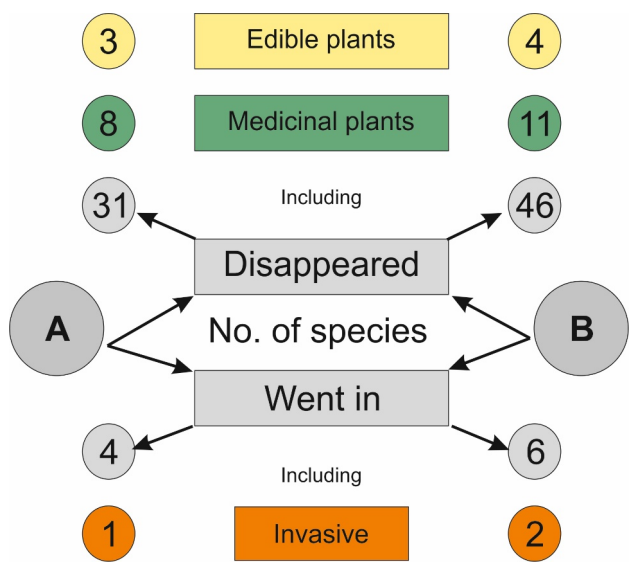

Figure 5. Consequences of the changes that occurred in the locations described by the A and $\mathrm{B}$ relevés. 
telemetric evaluations of plant cover. Regardless of the methodological aspect of taking a phytosociological relevé, the value of such surveys is of enormous environmental and economic significance and increases with the time between the first and last studies in a given area.

\section{Conclusion}

Comparisons of phytosociological relevés conducted at different times with long intervals between them have significant scientific and practical meaning. From a scientific point of view, they provide information on the dynamics of plant cover as related to human activity, climate change and all other factors affecting plant development. From a nature protection point of view, phytosociological data provide information on the dynamics of endangered and invasive species. From an economic point of view, the analysis of phytosociological relevés allows assessments of the effects of human activities. The example presented in this paper, which shows the effects of forest management on floristic changes over 60 years, can be treated as a case study, but considering how data are used and interpreted, this example is universal. For this example, one mistake made in the past, as part of forest management, has led to the disappearance of over $80 \%$ of the plant species in a given research area. The consequences of the disappearance of each species could be considered separately both in terms of nature as well as economically. In this context, phytosociology provides the opportunity to link to a number of additional studies, e.g., entomological or mycological, as well as social aspects in the field of human usage of natural resources. This shows that phytosociology is a tool that still has great and untapped potential.

\section{Acknowledgements}

Project financially co-supported by Minister of Science and Higher Education in the range of the program entitled "Regional lnitiative of Excellence" for the years 2019-2022, Project No. 005/RID/2018/2019/nauki leśne/.

\section{Conflicts of Interest}

The authors declare no conflicts of interest regarding the publication of this paper.

\section{References}

[1] Matuszkiewicz, W. (2002) Przewodnik do oznaczania zbiorowisk roślinnych Polski. PWN, Warszawa.

[2] Pawłowski B. (1977) Skład i budowa zbiorowisk roślinnych oraz metody ich badania. In: Szafer, W. and Zarzycki, K., Eds., Szata roślinna Polski, PWN, Warszawa.

[3] Braun-Blanquet, J. (1964) Pflanzensociologie. Grundzüge der Vegetationskunde. 3. Auflage Springer Verlag, Wien.

[4] Nowaczyk, C. (1964) Zespoły Leśne Nadleśnictwa Doświadczalnego Zielonka pod Poznaniem. Pr. Kom. Nauk Roln. Kom. Nauk Leśn. PTPN 17, 2, 213-269.

[5] Fornal-Pieniak, B. and Wysocki, C. (2011) Wybrane metody badań przekształceń 
szaty roślinnej. Acta Sci. Pol., Formatio Circumiectus, 10, 19-26.

[6] Bakker, J.P., Olff, H., Willems, J.H. and Zobel, M. (1996) Why Do We Need Permanent Plots in the Study of Long-Term Vegetation Dynamics? Journal of Vegetation Science, 7, 147-156. https://doi.org/10.2307/3236314

[7] Danby, R.K., Koh, S., Hik, D.S. and Prace, L.W. (2011) Four Decades of Plant Community Change in the Alpine Tundraof Southwest Yukon, Canada. AMBIO, 40, 660-671. https://doi.org/10.1007/s13280-011-0172-2

[8] Holzinger, B., Hülber, K., Camenisch, M. and Grabherr, G. (2008) Changes in Plant Species Richness over the Last Century in the Eastern Swiss Alps: Elevational Gradient, Bedrock Effects and Migration Rates. Plant Ecology, 195,179-196. https://doi.org/10.1007/s11258-007-9314-9

[9] Kullman, L. (2007) Long Term Geobotanical Observations of Climate Change Impacts in the Scandes of West-Central Sweden. Nordic Journal of Botany, 24, 445-467. https://doi.org/10.1111/j.1756-1051.2004.tb02209.x

[10] Vittoz, P., Randin, C., Dutoit, A., Bonnet, F. and Hegg, O. (2009) Low impact of climate change on subalpine grasslands in the Swiss Northern Alps. Global Change Biology, 15, 209-220. https://doi.org/10.1111/j.1365-2486.2008.01707.x

[11] Odland, A., Høitomt, T. and Olsen, S.L. (2010) Increasing Vascular Plant Richness on 13 High Mountain Summits in Southern Norway since the Early 1970s. Arctic, Antarctic, and Alpine Research, 42, 458-470. https://doi.org/10.1657/1938-4246-42.4.458

[12] Becker, T., Spanka, J., Schroder, L. and Leuschner, C. (2017) Forty Years of Vegetation Change in Former Coppice-with-Standards Woodlands as a Result of Management Change and N Deposition. Applied Vegetation Science, 20, 304-313. https://doi.org/10.1111/avsc.12282

[13] Hedl, R., Bernhardt-Römermann, M., Grytnes, J.-A., Jurasinski, G. and Ewald, J. (2017) Resurvey of Historical Vegetation Plots: A Tool for Understanding Long-Term Dynamics of Plant Communities. Applied Vegetation Science, 20, 161-163. https://doi.org/10.1111/avsc.12307

[14] Silvertown, J., Poulton, P., Johnston, E., Edwards, G., Heard, M. and Biss, P.M. (2006) The Park Grass Experiment 1856-2006: its contribution to ecology. Journal of Ecology, 94, 801-814. https://doi.org/10.1111/j.1365-2745.2006.01145.x

[15] Conard, H. and Galligar, G. (1929) Third Survey of a Long Island Salt Marsh. Ecology, 10, 326-336. https://doi.org/10.2307/1929509

[16] Kapfer, J. and Grytnes, J.-A. (2017) Large Climate Change, Large Effect? Vegetation Changes over the Past Century in the European High Arctic. Applied Vegetation Science, 20, 204-214. https://doi.org/10.1111/avsc.12280

[17] Archaux, F., Gosselin, F., Berges, L. and Chevalier, R. (2006) Effects of Sampling Time, Species Richness and Observer on the Exhaustiveness of Plant Censuses. Journal of Vegetation Science, 17, 299-306. https://doi.org/10.1111/j.1654-1103.2006.tb02449.x

[18] Ross, L.C., Woodin, S.J., Hester, A., Thompson, D.B. and Birks, H.J.B. (2010) How Important Is Plot Relocation Accuracy When Interpreting Re-Visitation Studies of Vegetation Change? Plant Ecology \& Diversity, 3, 1-8. https://doi.org/10.1080/17550871003706233

[19] Alfonsi, E., Benot, M.-L., Fievet, V. and Alard, D. (2017) Addressing Species Turnover and Community Changes in Vegetation Resurvey Studies. Applied Vegetation Science, 20, 172-182. https://doi.org/10.1111/avsc.12258 
[20] Britton, A.J., Hester, A.J., Hewison, R.L., Potts, J.M. and Ross, L.C. (2017) Climate, Pollution and Grazing Drive Long-Term Change in Moorland Habitats. Applied Vegetation Science, 20, 194-203. https://doi.org/10.1111/avsc.12260

[21] Navratilova, J., Hajek, M., Navratil, J., Hajkova, P. and Frazier, R.J. (2017) Convergence and Impoverishment of Fen Communities in a Eutrophicated Agricultural Landscape of the Czech Republic. Applied Vegetation Science, 20, 225-235. https://doi.org/10.1111/avsc.12298

[22] Schweiger, A.H. and Beierkuhnlein, C. (2017) The Ecological Legacy of 20th Century Acidification Carried on by Ecosystem Engineers. Applied Vegetation Science, 20, 215-235. https://doi.org/10.1111/avsc.12259

[23] Heinrichs, S. and Schmidt, W. (2017) Biotic Homogenization of Herb Layer Composition between Two Contrasting Beech Forest Communities on Limestone over 50 Years. Applied Vegetation Science, 20, 271-281. https://doi.org/10.1111/avsc.12255

[24] Reczyńska, K. and Świerkosz, K. (2017) Compositional Changes in Thermophilous Oak Forests in Poland over Time: Do They Correspond to European Trends? Applied Vegetation Science, 20, 293-303. https://doi.org/10.1111/avsc.12290

[25] Vild, O., Hedl, R., Kopecky, M., Szabo, P., Suchankova, S. and Zouhar, V. (2017) The Paradox of Long-Term Ungulate Impact: Increase of Plant Species Richness in a Temperate Forest. Applied Vegetation Science, 20, 282-292. https://doi.org/10.1111/avsc.12289

[26] Bernards, S.J. and Morris, L.R. (2017) Influence of Topography on Long-Term Successional Trajectories in Canyon Grasslands. Applied Vegetation Science, 20, 236-246. https://doi.org/10.1111/avsc. 12272

[27] Giarrizzo, E., Burrascano, S., Chiti, T., de Bello, F., Leps, J., Zavattero, L. and Blasi, C. (2017) Re-Visiting Historical Semi-Natural Grasslands in the Apennines to Assess Patterns of Changes in Species Composition and Functional Traits. Applied Vegetation Science, 20, 247-258. https://doi.org/10.1111/avsc.12288

[28] Koch, M., Schröder, B., Günther, A., Kerstin, A., Pivarci, R. and Jurasinski, G. (2017) Taxonomic and Functional Vegetation Changes after Shifting Management from Traditional Herding to Fenced Grazing in Temperate Grassland Communities. Applied Vegetation Science, 20, 259-270. https://doi.org/10.1111/avsc.12287

[29] Pakeman, R.L., Hewison, R.L. and Lewis, R.J. (2017) Drivers of Species Richness and Compositional Change in Scottish Coastal Vegetation. Applied Vegetation Science, 20, 183-193. https://doi.org/10.1111/avsc.12283

[30] Matuszkiewicz, W. (2006) Przewodnik do oznaczania zbiorowisk roślinnych Polski. PWN, Warszawa.

[31] Hereźniak, J. (1992) Amerykańskie drzewa i krzewy na nizinach polskich. In: Ławrynowicz M., Warcholińska A. U.: Rośliny pochodzenia amerykańskiego zadomowione w Polsce. Łódzkie Towarzystwo Naukowe. Szlakami Nauki, 19, 97-150.

[32] Tomanek, J. (1997) Forest Botany (In Polish: Botanika leśna). PWRiL Warszawa.

[33] Grajewski, S., Jankowski, K. and Licznierski, M. (2010) Czeremcha amerykańska Prunus serotina Ehrh. w polskich lasach na przykładzie drzewostanów Nadleśnictwa Doświadczalnego Zielonka oraz Nadleśnictwa Szubin. Zarządz. Ochr. Przyr. w Lasach. Wyd. WSZŚ w Tucholi, 4, 39-55.

[34] Konatowska, M. (2018) Porównanie zbiorowisk roślinnych w Nadleśnictwie Doświadczalnym Zielonka z połowy XX i początku XXI wieku. PhD Dissertation. 